\title{
The Human Right to Social Security and Its Impact on Socio-Political Action in Germany and Finland
}

\author{
Ingo Stamm ${ }^{1}$ (D)
}

Published online: 6 May 2017

(C) Springer International Publishing 2017

\begin{abstract}
Social human rights have rarely been given attention in social work research or comparative studies on welfare states. The paper aims at filling the gap by analysing the conception of human beings inherent in human rights and in unemployment policy documents in Germany and Finland. Its focus lies on the right to social security, a central norm of the International Covenant on Economic, Social and Cultural Rights. The main question is what impact does the right to social security have on socio-political action in Germany and Finland. The results of the analysis, which was based on the objective hermeneutics, revealed a structural similarity between the conceptions of human beings in both countries. Unemployed people are labelled as deficient and potentially in need of educational measures. Their autonomy is curtailed, sometimes severely. In this sense, the right to social security has hardly any impact. The social work profession in theory and practice should use human rights as a tool against these new forms of oppression.
\end{abstract}

Keywords Social human rights $\cdot$ Social security .

Unemployment policies · Conception of human beings .

Comparative research on welfare states $\cdot$ Objective hermeneutics

Ingo Stamm

Ingo.Stamm@chydenius.fi

1 University of Jyvaskyla, Kokkola University Consortium Chydenius, PL 567, 67701 Kokkola, Finland

\section{Introduction}

In the summer of 2011, economic, social and cultural human rights received significant media coverage in Germany. A consortium of around 20 German non-governmental organisations - among them initiatives of social workers-composed an alternative report on the realisation of the International Covenant on Economic, Social and Cultural Rights (ICESCR) and sent it to the responsible United Nations committee in Geneva. Among the most salient topics were the situation of elderly in care homes and poverty in Germany (Staub-Bernasconi 2016: 47). The committee is obliged to consider these reports as well as the obligatory state reports. The final outcome of the procedure is always the publication of so-called "concluding observations". Several newspapers reported about the recommendations and concerns of the committee included in the concluding observations (Meisner 2011; Spiegel-Online 2011). In some newspaper articles, the whole state reporting procedure was treated with a great amount of scepticism and therefore it was even easier for the German government to wipe away any concerns. To cut a long story short, the German Government claimed that the accusations of the committee were exaggerated and made without an in-depth knowledge of the German welfare system. The discussion about international social standards ended as soon as the summer slump was over.

Despite numerous international treaties on social standards, national law and international law are barely brought together. The most important treaties were developed by the International Labour Organisation, for example the ILO Convention 102 concerning Minimum Standards of Social Security (ILO 2017), the European Council, most notably the European Social Charter (Revised) (COE 2017), and the 
United Nations (OHCHR 2017a). Whereas in the global south, there is a lively discussion on global social rights (cf. Fischer-Lescano and Möller 2012), it seems that in European states the social dimension of human rights is more symbolic in nature. Social human rights ${ }^{1}$ can be seen as "forgotten" (Weiß 2000: 40) or "neglected human rights" (StaubBernasconi 2007: 138). These claims are related to the historical development of human rights, as well as to the fact that they mostly have not been integrated in national constitutions. However, they are not only forgotten or neglected in lawmaking processes; social human rights play almost no role also in comparative studies on welfare states (Kaufmann 2003a: 41). Social rights are either only discussed as a basis for the realisation of social citizenship in a national context (Esping-Andersen 1990: 35) or just mentioned but not integrated in the studies as comparative elements (cf. Kaufmann 2012). In social work, the awareness about human rights has grown during the last 20 years, but the "new paradigm" (Reichert 2007: 1) of social work as a human rights profession has not been created everywhere and has not reached all countries and professionals. Very few scholars have tried to connect and compare social policy standards and specific human rights treaties or norms. There have for example been attempts to compare and analyse national constitutions and the Universal Declaration of Human Rights (UDHR) (Wronka 1998; Staub-Bernasconi 2016).

The identification of this gap was the starting point for this study (cf. Stamm 2015). It highlights the connection between human rights and national social policies and asks what impact social human rights have on social policies. Its primary focus is on the right to social security and in particular on the risk of unemployment. The right to social security can be considered as a principle norm within the ICESCR, which encompasses all other articles (Scheinin 2001: 211). The reasons to choose the risk of unemployment are manifold. To follow Castel (2011: 37), employment is even more than in the past at the "epicentre" of the social question. Finally, it discusses the role of social workers supporting and cooperating with unemployed people and asks what implications social human rights can have for the practice of social work.

The aim was to fill the above-mentioned gap by analysing the field of job market-related social security in Germany and Finland. Both countries have faced severe economic crises during the last 25 years, and unemployment has always been a key issue in the controversial national debates. These debates have led to several reforms mostly in the field of unemployment and in regard to so-called activation policies (cf. Lessenich 2008; Kangas and Saari 2008). Based on the classic

\footnotetext{
${ }^{1}$ In this paper the term social human rights serves as a generic clause and is used as a synonym for social, economic and cultural human rights. This is due to the common use of the term in German-speaking countries (cf. Krennerich 2013). It emphasises the interconnectedness of these rights.
}

categorisation by Esping-Andersen, Germany and Finland are examples of the conservative and the social-democratic type of welfare states. The initial hypothesis was to have two contrasting cases. The empirical part of the study was centred around the conception of human beings (German: Menschenbild). ${ }^{2}$ The conception of human beings was used as an indicator of the effective power of the chosen human right. The study proceeded in two steps: Firstly, social security-related national documents from both countries were searched to find the implicit conception of human beings. The analysis was conducted by using the text interpretation method of the objective hermeneutics (Oevermann 1981, 2000; Wernet 2009). Subsequently, the conception of human beings detected in each country was contrasted with the concept of human beings inherent in human rights documents, which regard human beings primarily as holders of individual, universal and inalienable rights (cf. Gosepath 1998; Brugger 2007; Menke and Pollmann 2007). Following this, the similarities and differences between the two countries were identified.

The paper starts by illustrating the theoretical background of social human rights and the connection between social work and human rights. This part is concluded with a short description of the core elements of the right to social security within the system of the United Nations. The results of the twofold comparison will be presented after a justification of the methodological approach and a description of the chosen documents related to German and Finnish unemployment policies. Despite their different roots, a structural similarity between the conception of human beings in German and Finnish documents could be identified. The paper closes with a discussion on how these findings could affect social work. The paper follows an interdisciplinary approach, mostly combining sociological research on welfare states, human rightsbased social work and international law. It should provide insights on the connectedness of social human rights and national welfare state provisions as well as instructions for using human rights as a tool in social work practice.

\section{Social Human Rights and the Right to Social Security in the UN System}

Before delineating social human rights and the right to social security within the framework of the United Nations, a few important general statements about the "Janus face of human

\footnotetext{
${ }^{2}$ In German-speaking countries Menschenbild is a well-known term not only used in academic debates. For example, it is used in the on-going discussions about the homo oeconomicus as the dominating Menschenbild in economics (cf. Kutzner 2007). There is no clear English translation to the knowledge of the author. Possible translations are idea of man, image of humanity as well as conception of human nature. In this paper the term conception of human beings is used because it is not biased and describes the original meaning best.
} 
rights" (Habermas 1999: 391) should be made. The development of human rights can be divided into two time periods: One before and one after the formation of the United Nations. In short, this change could be described as a fast transition from pure moral rights, based on the nature of human beings, to litigable rights of individuals guaranteed by states. But even with the establishment in international law, there is not only one definition or perception of human rights. Debates on the idea, concept and application of human rights, also in different cultural settings, are constantly ongoing. Ife suggests not seeing human rights "as existing objectively but as social constructions" (2007: 84). They are not only part of international law but should also reverberate with the daily struggles of people and social work practice. A common categorisation is the three-generation concept of human rights: the first generation is so-called civil and political rights, the second are social, economic and cultural rights and the third are collective human rights (cf. Wronka 1998). The latter group of rights is also emphasised in the current Global Definition of the Social Work Profession and its commentary notes, which focus not only on individual rights but also on collective responsibilities and the "inter-dependence among people and between people and the environment (IFSW 2017). The generation concept of human rights has often been criticised, for example for suggesting a hierarchy with civil and political rights at the top. But the historical development did not happen in such a linear way, and also the division between individual and collective rights is not at all clear. All human rights can be seen as interconnected and indivisible, with individual and collective elements (Ife 2012: 66). The right to life for example corresponds with the right to food (enshrined in the ICESCR under article 11), which on the other hand is strongly connected to a healthy environment. It has taken a long time to prove that economic, social and cultural rights cannot be categorically separated from civil and political human rights. Some critics saw the incorporation of social standards into the human rights system of the United Nations as a burden and argued that human rights would be pushed "out of the clear realm of the morally compelling into the twilight world of utopian aspiration" (Cranston 1973: 68). Others did not believe in the justiciability of social human rights when resources are scarce but entitlements are kept. One way to show the inseparability is to focus on state obligations. Shue created the idea of a triad of obligations: He described them in short as the "duties to avoid, to protect and to aid" (1996: 51-64). States are therefore obliged to (1) not violate the rights of others, (2) protect persons from rights violations and (3) aid those whose rights are violated. It can be easily demonstrated, also with the right to social security, that these obligations are not only important for civil and political rights, but for all. Social rights are not just a form of socialist state intervention, and civil rights are not simply a liberal defence against the state (Bielefeldt 1998: 101).

The rationale of social human rights can be based on the perception that everybody has an equal entitlement to freedom and an equal entitlement to basic needs and is generally founded on the moral obligation to an equal distribution of goods. Therefore, the idea of social justice mainly constitutes the idea of social rights of all human beings (Gosepath 1998, 2004). This corresponds with the Global Definition of the Social Work Profession, which states that the "...principles of social justice, human rights, collective responsibility and respect for diversities are central to social work" (IFSW 2017). Many social workers might rely on social justice as a guiding principle, as described by Reichert $(2003,2007)$ in regard to the USA, even though by no means all social workers have a clear idea about the concept of social justice and what it might imply for the practice (cf. Hölscher 2012). This is also due to a missing concrete definition of social justice. Generally, in a social work context, it seems to be mostly associated with egalitarian theories and a fair and inclusive society (Reichert 2003: 9). The realisation of social human rights can be viewed as a precondition for social justice. In other words, human rights "can serve as a guide to putting into operation the often vague concept of social justice" (Mapp 2014: 12). They do not inform social workers about how to act ethically in every difficult professional decision. But, as will be shown with this study, they provide better understanding about ethical questions regarding certain rights, and they open the "possibility of dialogue" (Ife 2007: 81). For this study, the focus lies on the perspective that all human rights are based on the idea of autonomy. The obstacle to an autonomous life can be a lack of freedom as well as a lack of (social) security (Gosepath 2004: 314). This perception can certainly be contested. As indicated before, human rights also have a collective dimension. They are not only individual rights guaranteeing autonomy but also relational rights important for example for community development (cf. Ife 2012, 2016).

The origins of the right to social security can be traced back to the time period between the world wars: social security became an influential term during the Great Recession in the 1930s in the USA. It served as a leitmotif for the comprehensive social reforms resulting from the crisis (cf. Kaufmann 2003b). Later, it became a guiding principle for the British Beveridge-Plan in Great Britain, and also in Germany it gained some popularity as the "Erbe der Aufklärung" [heritage of the enlightenment]" (Achinger 1953: 19). The right to social security in an international context was first introduced by the International Labour Organisation in 1944. A few years later, the right found its way into the UDHR in articles 22 and 25 . One of the main advocates for social rights in the process of developing the declaration was Eleanor Roosevelt. She had a significant influence on giving them a prominent position in the document. Despite this, the Cold War made it impossible to compose one strong and binding covenant on all human rights enshrined in the UDHR. In the end, two covenants were adopted in 1966. The right to social security is the shortest article (9) of the International Covenant on Economic, Social and Cultural Rights. It states: "The States Parties to the present 
Covenant recognize the right of everyone to social security, including social insurance" (Reichert 2003: 282). The covenant entered into force in 1976 after being ratified by the required 35 states (cf. Craven 1998). However, it took much more time for article 9 to be taken into further consideration by the Committee on Economic, Social and Cultural Rights (CESCR), which is responsible for monitoring the activities of the treaty members (Scheinin 2001; Riedel 2007). In 2007, the committee adopted a so-called general comment on the right to social security (No. 19) (CESCR 2008). These comments are important documents for clarifying the content of the enshrined rights and connected state obligations. So far the CESCR has adopted 23 general comments (as per March 2017; OHCHR 2017b). They can also serve social workers to better understand the core principles of certain rights.

The general comment No. 19 emphasises in the introduction the "central importance [of the right] in guaranteeing human dignity for all persons when they are faced with circumstances that deprive them of their capacity to fully realize their Covenant rights" (CESCR 2008, para. 1). The right to social security "encompasses the right to access and maintain benefits, whether in cash or in kind, without discrimination in order to secure protection" (para. 2). The general comment then lists nine social risks and contingencies which might require protection, among them the risk of unemployment. All member states have to take steps to provide security to all in case of unemployment without discrimination of certain groups. The comment further identifies three elements of the right: availability, adequacy and accessibility. Member states are asked to implement national strategies organised according to these three main elements of the right. The implicit conception of human beings of the human rights system can be clearly found in the general comment No. 19. Human beings are primarily seen as persons with fundamental rights. Everybody has an individual right to social security in the case of unemployment. Social security aims at balancing the lack of economic autonomy caused by a missing income. It is therefore also very much connected to the right to work (article 6, ICESCR). An overview of economic human rights can be found in Hertel and Minkler (2007).

As briefly demonstrated, the human right to social security has a long history and its meaning and content is nowadays elaborated very well. Nevertheless, the right does not play a significant role in social work or in comparative research on welfare states.

\section{Country Case Studies and Methodological Approach}

The study was conducted by using the methodological framework of the objective hermeneutics. The central question was what impact the right to social security has on socio-political action in Germany and Finland. Socio-political action in this context primarily means the composition of legal texts. Therefore, legal documents were chosen as units of analysis for the text interpretation method according to the principles of the objective hermeneutics. The two selected countries Germany and Finland served as the two cases of the study.

There were manifold reasons for choosing objective hermeneutics as the methodological approach. In general, objective hermeneutics follows the logic of reconstruction and opposes classificatory approaches that aim at simple subsumption (cf. Oevermann et al. 1979; Oevermann 1981, 2000; Reichertz 2004; Wernet 2009). According to the objective hermeneutics, the world is meaning-structured and constituted through language and texts. Access to the meaningful structure of the world can therefore only be gotten through protocols (texts) of the Lebenswelt (life world). Text is a wide ranging term in the framework of the objective hermeneutics. Texts can be actions protocolled in many different ways (Oevermann et al. 1979: 368). In general, every analysis within the objective hermeneutics aims at revealing the "latent meaning structure" (Oevermann 1981: 5). The method of interpretation is an in-depth analysis based on the principles of extensity and sequentiality. Every text interpretation unit should lead to a hypothesis about the case structure. Saturation is reached when the case structure hypothesis does not change significantly after the researcher has repeatedly followed the specific steps of the interpretation method (Wernet 2009: 80). A detailed description of the steps of analysis used in this study can be found in Stamm (2015).

According to the methodological approach of the objective hermeneutics, the legal documents (protocols) used for the analysis are a form of documentation of socio-political action. The use of the method was very instructive since the goal was to search for an implicit conception of human beings in the units of analysis. At the beginning, the analysis was based on the hypothesis that a conception of human beings cannot be easily identified; that it is not directly mentioned or even explained and therefore not manifest. Nevertheless, it is always latently contained and can be found in all documents.

The decision to choose Finland and Germany was mainly based on the classical categorisation by Esping-Andersen (1990, 1999). Germany is often seen as the prototype of a conservative welfare state and Finland as a member of the Scandinavian, social-democratic "world" of welfare states. The conservative welfare state is thus built on collective bargaining agreements between companies and unions and emphasises the importance of income-based social insurance systems. Families play a significant role for social protection. Social rights are bound to the class and status of citizens. The foundation of the social-democratic model are universal systems of social security and social rights are usually equally guaranteed for all citizens. The degree of de-commodification, a central category for Esping-Andersen in his study, is the 
lowest among all welfare states (Esping-Andersen 1990: 74). De-commodification "occurs when a service is rendered as a matter of right, and when a person can maintain a livelihood without reliance on the market" (Ibid: 21). The guiding hypothesis for the comparative element of the study was to have two contrasting cases with Germany and Finland. Apart from this, Finland is a relatively unknown welfare state. It seems to have often stood in the shadow of the very well-known Swedish model. Only the educational sector has been of academic interest internationally as the excellent results of Finnish school students in surveys like Pisa have gained worldwide attention (cf. Matthies and Skiera 2009).

For this study, the most important legal texts and other documents in the sector of unemployment policies for both countries were chosen for analysis. As a starting point, the central law on job market-related social security in Germany (Social Book II-basic security for job seekers - first version from 2003) and a rather similar law in Finland (Job market support law-first version from 1993) were analysed. Based on the results, further documents were interpreted. For the German case, the report of the Hartz-Commission from 2002 and a brochure published by the Federal Employment Agency in 2012 were analysed. The first one is a decisive document since it was the basis for the very controversial reforms on unemployment policies in 2004 (so-called Hartz reforms). The latter is highly informative since it translates the legal text for the local job centres and directly addresses unemployed people. For the Finnish case the Social Assistance Act from 1997, the law on security in the case of unemployment from 2002 and also a brochure for job seekers, published by the Employment and Economic Development Office in 2012, were used for text interpretations. The documents for Finland are encompassing a time period of 20 years. Documents from the early 1990s are included as Finland had already started to reform its unemployment policies during that time, a reaction to the severe economic crisis in the country that started in 1991 (cf. Kangas and Saari 2008; Keskitalo 2008; Van Aerschot 2011). In Germany, extensive job market reforms were undertaken approximately 10 years later by the Government coalition of the Social-Democratic and the Green Party (cf. Schmid 2007; Lessenich 2008; Dingeldey 2011).

\section{Unemployed People as Objects of Educational Measures}

The analysis revealed two structurally similar cases. The conception of human beings identified in the documents is rather similar in Germany and Finland. In both countries, unemployed people are mostly seen as deficient job market stakeholders who need to be parented in the way they take action to fulfil the societal norm of employment. The action taking is stipulated and is sometimes even forced. For unemployed people, this means that their unemployment and dependence on a system of social security is sometimes accompanied by a massive loss of autonomy. This structure can be found in both countries. Nevertheless, the analysis of the German documents brought a clear case structure to light, whereas the analysis of the Finnish documents is more complex. The similarities will be elaborated on first.

In both countries, unemployed people lose their freedom to act to a significant extent along with the above-described loss of autonomy. The paramount aim of the policy maker is without a doubt integration into the job market. This aim is supposedly also in line with the aims of almost all unemployed people and is also in line with the right to social security. But what is remarkable is the coercive character of many measures. If an unemployed person does not act in favour of the unemployment authorities, he or she has to fear sanctions, which could also be called a parenting tool. Sanctions often include a cut or even a complete abatement of benefits. This comprehensive control of unemployed people can be found in almost all documents, but it seems to have become stronger with time. In Germany, the Hartz report introduces the idea of fixing the problem of unemployment and educating the jobless. The state of unemployment is compared with delinquency. The unemployed person becomes someone who lost the right path and stands outside of society. In Germany, the controversial word "Eingliederung" is used for the process of reintegration. Unemployed people have to show evidence that there are no reasonable jobs available, and if they cannot provide it, they are not anymore obliged to receive support (Stamm 2015: 84). The text of the Social Book II continues to identify deficits in the character of unemployed people. They are seen as immature and dependent and therefore in need of education. They do not understand the value of an independent life; the goal of the educational programme is to build what the German law calls Eigenverantwortung (individual or self-responsibility). The document describes a paradoxical strategy: first, unemployed people are incapacitated, in order to form then responsible and independent job market actors (ibid: 94). The coercive character of the German unemployment policies is shown in the most precise way in the job centre brochure. For example, when the author of the text identifies the elimination of the neediness of unemployed people as the first goal. They are considered as not willing to integrate or re-integrate into the job market, and they are needy as a whole (the German documents use the term Hilfebedürftigkeit to describe this state). In the next paragraph, the author threatens that the beneficiaries and their families will have to face far-reaching consequences in case of disobedience (Stamm 2015: 104). The results of the Finnish documents do not follow such a clear and consistent way. The text of the law for job market support identifies unemployed people first as people with a temporary need for economic 
support. At the same time, they are primarily addressed as job market protagonists and not as citizens with basic social rights (ibid: 134). The act on social assistance then displays firstly the goal of rehabilitation of "man power". To reach this goal the Finnish state introduces coercive measures by presenting a catalogue of benefit cuts and other consequences in cases where the unemployed do not cooperate according to the law (ibid: 145). This notion of unwillingness to work and cooperate can also be seen in the law on security in the case of unemployment. As will be shown below, also included are structural reasons for unemployment. Nevertheless, unemployed people have to face a loss of autonomy (ibid: 157). Again, as it has been the case for Germany, the coercive character of unemployment policies is most clearly presented in the latest document, the brochure for unemployed people. The job market is described here as an authority, even as a master to whom the unemployed should always be available. In case of refusal, unemployed people will have to face a so-called waiting period without benefits of up to 90 days. And at the very end of the paragraph, the Finnish lawmaker puts into brackets the core of the whole text quite clearly - it is about an "obligation to work" (Stamm 2015: 165).

The difference of the case structure found in the two countries is a qualitative one. More concretely, the quality of how much the autonomy of unemployed people is deprived. Germany is much more parenting than Finland. The measures are therefore more coercive in the homeland of one of European's oldest welfare states. The analysed documents clearly show that unemployed people are directly and individually made responsible for their loss of employment. The whole person is described as deficient, not only their missing capabilities to perform on the job market. This way of blaming unemployed people could not be found in the Finnish documents. In the law on security in the case of unemployment, the state of unemployment is even compared with a natural disaster and therefore as something fateful. This might be based on the long tradition of active (not activating) job market policies in Finland, which have always focused more on structural problems than on individual ones. The characteristics of "active" and "activating" job market policies are therefore worth studying, also from a social work perspective and in relation to the different "regimes" of welfare states (Knuth 2005; Dingeldey 2011). The qualitative difference of the case structure might affect the level of implementation, something which could not be taken into consideration in this study. Nevertheless, both countries chose coercive measures to change the deficient character of the unemployed.

\section{Conclusion}

The aim of this paper was to reflect on the connectedness between social human rights and national social policies. It asked what impact does the (human) right to social security has on socio-political action in Germany and Finland. Based on that, the following questions were asked: What conclusions can be drawn regarding the different welfare state types? What role do social workers play? What could be learned for the social work profession? The direct results from the text interpretations show that the identified conception of human beings in the German and Finnish documents greatly contrasts with the conception of human beings inherent in human rights. Security does not have a value by itself. Only the functionality of security as a presupposition for the successful performance of unemployed people in the job market is important. As a reminder, the main function of social security is to absorb the consequences of life risks and to prevent people from poverty and societal descent. This is what a right to social security is based on, and it should be guaranteed by governments and state institutions. It emphasises and aims at promoting the autonomy of all people - despite their current state of economic hardship. This does not mean that the state should be the ultimate provider and take all responsibilities away from individuals. The search for paid work is still primarily an individual obligation (with a corresponding right to work emphasising the obligation of states and the society to ensure that jobs or meaningful work is available; also enshrined in the ICESCR, article 6). Nevertheless, to take the fulfilment of personal obligations as a condition for support is not acceptable from a human rights perspective. The curtailment of unemployed people's autonomy is a violation of the basic human rights principle of freedom (Bielefeldt 2011: 127). In a nutshell, the conditionality of the right to social security and its consequences is what makes the structure in Germany and Finland similar. To summarise the results, on one hand, there is a deprivation of autonomy for the sake of an employment society on the national level and on the other hand, the human rights system strives for securing equal autonomy. The impact of the human right to social security is therefore almost invisible in this sense. The right is only partly guaranteed in both states; the promise of autonomy implied in all human rights is not fully kept.

What implications do the results of the text interpretations have on the classical categorisation of welfare states? The fact that Germany and Finland are structurally similar against the background of the main research question leads to the simple assumption that differences between the two types are disappearing. Very generally, one can easily see that the main trait of the social-democratic type-"decommodification"-is no longer a reality in Finland. Esping-Andersen (1990) considered de-commodification as being in place when "citizens can freely, and without potential loss of job, income, or general welfare, opt out of work when they themselves consider it necessary" (ibid: 23). This option for Finnish citizens does not exist (anymore). It seems that this is true also for Sweden and other 
Scandinavian countries (cf. Van Aerschot 2011; Dingeldey 2011). Historically, the work ethic has always been very strong in Finland. There was even an undisputed obligation to work for the unemployed until the 1970s (Saari 2001: 254). But this was always connected to a right to work. More than in Germany, the Finnish state felt responsible for providing work for people. Some scholars see the big economic crisis in the early 1990 s as the turning point towards the activation paradigm and away from the "traditional" work ethic (Van Aerschot 2011). In Germany the close connection between social rights and status or class is increasingly vanishing. This at least counts for all unemployed people without entitlement to unemployment insurance benefits. All "addressees" of Social Book II, which was part of the analysis for this study, have equal rights and entitlements. Special benefits were abolished and the treatment is the same for all regardless of background - according to the law. Only young unemployed people have to face more severe sanctions in case of a misdemeanour. The number of beneficiaries of income-related unemployment insurance benefits (Social Book III) is diminishing at the same time (cf. Dingeldey 2010). Overall, both countries face a development towards "re-commodification", which was mainly predicted for the liberal welfare state at the beginning of the century (Pierson 2001: 455). Following the activation paradigm, "re-commodification" has now obviously reached all welfare states (Dingeldey 2011: 458).

A social work perspective also has to take into account the implementation of legal regulations. Maybe analysing legal documents cannot provide reliable information about the real situation of unemployed people? For both countries, studies present quite clear evidence that the findings of the analysis of legal documents are also reflected in the practice of unemployed services. In Germany, Ludwig-Mayerhofer et al. (2009) interviewed a large number of case workers in German job centres for a comprehensive study about the "crisis of unemployment". They found that for most of these case workers, activation clearly also means parenting the unemployed. They would take the role of educators without reflecting on it. Supporting unemployed people is first and foremost a process of rational and efficient controlling of reluctant people (ibid: 128). The conception of human beings inherent in human rights is therefore also missing on the level of implementation. In Finland similar tendencies are described by identifying an ambivalent role of administrational staff in unemployment agencies from the perspective of unemployed people: "... their duty is to try to improve his/her situation but their intervention may result in its degradation" (Van Aerschot 2011: 37). The level of implementation is also where social work research could make an important contribution in the future based on this study. Further studies could describe how social security law is transferred to the practice and analyse the consequences for unemployed people. In Germany this could for example include young unemployed people under 25 years who lost their entitlement to any financial support and who sometimes even have to face homelessness.

This leads to the question of social work and its ethical foundation in the field of unemployment policies. Social workers are often involved in counselling or support programmes for unemployed people and job seekers. But are they aware of what obligations social human rights place on the social work profession and state institutions? Do social work students learn about social and economic human rights such as the rights to social security and the right to work? Or do they only learn to accept and "use" national social policies despite their problematic nature? And how could human rights in the field of social security be made applicable in certain countries and societies in cooperation with social work clients, so that they become what Ife calls "human rights from below" (2007: 86). These are important questions for both the profession and social workers to discuss. They seem to be more important than ever in times of "re-commodification" of European welfare states. As the results show, activation polices in Finland and especially Germany can lead to new forms of oppression of unemployed and often poor people. Challenging oppression can be seen as one of the main interventions in the social work profession that is directly connected to human rights (Reichert 2003: 228). Therefore, social workers should identify oppressive structures and use human rights to challenge them. Another intervention is empowerment of people (ibid: 229). Activation polices often claim to help people become active and independent again. Social workers could report from their work with unemployed people about the effects of certain policies and make clear that activation measures are often not empowering but have the opposite effect. They should inform their clients about their rights and support them for example in writing appeals against decisions made by employment services. In both countries integrating these interventions more concretely could already make a significant difference. It can also imply a stronger cooperation with national associations of social workers in order to gain a stronger political voice. One first step to empower the social work profession would be to strengthen the knowledge base about the connection between social human rights and social policies. Social workers should know more about social human rights and related documents, such as the general comments by the Committee on Economic, Social and Cultural Rights. They can serve as a platform to question and discuss the concrete connections between human rights and specific fields of social work-within social work organisations and directly with the clients. The focus on the conception of human beings can serve as the basis to start these discussions. It can mean a crucial change of perspective to see clients as holders of universal and inalienable human rights. This 
change of perspective can lead to a different kind of action of social workers in cooperation with their clients.

\section{References}

Achinger, H. (1953). Soziale Sicherheit. Eine historisch-soziologische Untersuchung neuer Hilfsmethoden. Stuttgart: Friedrich Vorwerk.

Bielefeldt, H. (1998). Philosophie der Menschenrechte. Grundlagen eines weltweiten Freiheitsethos. Darmstadt: Primus.

Bielefeldt, H. (2011). Auslaufmodell Menschenwürde? Warum sie in Frage steht und warum wir sie verteidigen müssen. Freiburg: Herder.

Brugger, W. (2007). Zum Verhältnis von Menschenbild und Menschenrechte. In W. Härle \& B. Vogel (Eds.), Vom Rechte, das mit uns geboren ist. Aktuelle Probleme des Naturrechts (pp. 216247). Herder Verlag: Freiburg.

Castel, R. (2011). Die Krise der Arbeit. Neue Unsicherheiten und die Zukunft des Individuums. Hamburg: HIS Hamburger Edition.

CESCR - Committee on Economic, Social and Cultural Rights (2008). General Comment No. 19. The right to social security (art. 9). E/C.12/GC/19. http://tbinternet.ohchr.org/_layouts/ treatybodyexternal/Download.aspx?symbolno=E $\% 2 \mathrm{fC} .12 \%$ 2fGC\%2f19\&Lang=en. Accessed 28 Feb 2017.

COE - Council of Europe (2017). European Social Charter (Revised). https://rm.coe.int/CoERMPublicCommonSearchServices/ DisplayDCTMContent?documentId=090000168007 cf93. Accessed 22 Feb 2017.

Cranston, M. (1973). What are human rights? London: The Bodley Head.

Craven, M. (1998). The international covenant on economic, social and cultural rights. A perspective on its development. Oxford: University Press.

Dingeldey, I. (2010). Agenda 2010: Dualisierung der Arbeitsmarktpolitik. Aus Politik und Zeitgeschichte, 48, 18-25.

Dingeldey, I. (2011). Der aktivierende Wohlfahrtsstaat: Governance der Arbeitsmarktpolitik in Dänemark, Großbritannien und Deutschland. Campus: Frankfurt a. Main.

Esping-Andersen, G. (1990). The three worlds of welfare capitalism. Cambridge: Polity Press.

Esping-Andersen, G. (1999). Social foundations of postindustrial economies. Oxford: University Press.

Fischer-Lescano, A., \& Möller, K. (2012). Der Kampf um globale soziale Rechte: Zart wäre das Gröbste. Berlin: Wagenbach.

Gosepath, S. (1998). Zu Begründungen sozialer Menschenrechte. In S. Gosepath \& G. Lohmann (Eds.), Philosophie der Menschenrechte (pp. 146-187). Frankfurt a. Main: Suhrkamp.

Gosepath, S. (2004). Menschenrechte als Grundsicherung. In C. Mahler \& N. Weiß (Eds.), Menschenrechtsschutz im Spiegel von Wissenschaft und Praxis (pp. 90-109). Berlin: BWV.

Habermas, J. (1999). Zur Legitimation durch Menschenrechte. In H. Brunkhorst \& P. Niesen (Eds.), Das Recht der Republik (pp. 386403). Frankfurt a. Main: Suhrkamp.

Hertel, S., \& Minkler, L. (Eds.). (2007). Economic rights. Conceptual, measurement, and policy issues. Cambridge: University Press.

Hölscher, D. (2012). Social justice. In L. M. Healy \& R. J. Link (Eds.), Handbook for international social work: human rights, development \& the social work profession (pp. 43-51). Oxford: Oxford University Press.

Ife, J. (2007). Cultural relativism and community activism. In E. Reichert (Ed.), Challenges in human rights. A social work perspective (pp. 76-96). New York: Columbia University Press.
Ife, J. (2012). Human rights and social work. Towards rights-based practice (Third ed.). Cambridge: University Press.

Ife, J. (2016). Human rights and social work: beyond conservative law. Journal of Human Rights and Social Work, 1, 3-8.

IFSW - International Federation of Social Workers (2017). Global Definition of the Social Work Profession. http://ifsw.org/getinvolved/global-definition-of-social-work/. Accessed 23 Feb 2017.

ILO - International Labour Organization (2017). C102 Social Security (Minimum Standards) Convention, 1952. http://www.ilo.org/dyn/ normlex/en/f?p=NORMLEXPUB:12100:0::NO::P12100 INSTRUMENT_ID:312247. Accessed 22 Feb 2017.

Kangas, O., \& Saari, J. (2008). Krisenbewältigung mit Langzeitfolgen? Der finnische Wohlfahrtsstaat. In K. Schubert, S. Hegelich, \& U. Bazant (Eds.), Europäische Wohlfahrtssysteme. Ein Handbuch (pp. 239-262). VS Verlag: Wiesbaden.

Kaufmann, F.-X. (2003a). Die Entstehung sozialer Grundrechte und die wohlfahrtsstaatliche Entwicklung. Paderborn: Schöningh.

Kaufmann, F.-X. (2003b). Sicherheit: Das Leitbild beherrschbarer Komplexität. In S. Lessenich (Ed.), Wohlfahrtsstaatliche Grundbegriffe. Historische und aktuelle Diskurse (pp. 73-104). Frankfurt a. Main: Campus.

Kaufmann, F.-X. (2012). Variations of the welfare state. Great Britain, Sweden, France and Germany between capitalism and socialism. Heidelberg: Springer.

Keskitalo, E. (2008). Balancing social citizenship and new paternalism. Finnish activation policy and street-level practice in a comparative perspective. Helsinki: Stakes.

Knuth, M. (2005). Reflexionen zum deutschen Reformpfad vor dem Hintergrund der Erfahrungen westeuropäischer Nachbarn. In H. Burghardt \& R. Enggruber (Eds.), Soziale Dienstleistungen am Arbeitsmarkt. Soziale Arbeit zwischen Arbeitsmarkt- und Sozialpolitik (pp. 175-192). Juventa: Weinheim.

Krennerich, M. (2013). Soziale Menschenrechte. Zwischen Recht und Politik. Schwalbach: Wochenschau-Verlag.

Kutzner, S. (2007). Das Menschenbild in der Schweizer Sozialhilfe: Utilitaristische Deutung und paternalistische Interventionen im "aktivierenden" Hilfesystem. In W. Ludwig-Mayerhofer, O. Behrend, \& A. Sondermann (Eds.), Fallverstehen und Deutungsmacht. Akteure in der Sozialverwaltung und ihre Klienten (pp. 143-166). Opladen: Barbara Budrich.

Lessenich, S. (2008). Die Neuerfindung des Sozialen. Der Sozialstaat im flexiblen Kapitalismus. Bielefeld: transcript.

Ludwig-Mayerhofer, W., Behrend, O., \& Sondermann, A. (2009). Auf der Suche nach der verlorenen Arbeit. Arbeitslose und Arbeitsvermittler im neuen Arbeitsmarktregime. Konstanz: UVK.

Mapp, S. C. (2014). Human rights and social justice in a global perspective. An introduction to international social work (Second ed.). Oxford: Oxford University Press.

Matthies, A.-L., \& Skiera, E. (Eds.). (2009). Das Bildungswesen in Finnland. Bad Heilbrunn: Klinkhardt.

Meisner, M. (2011). Vereinte Nationen rügen deutsche Sozialpolitik, Tagesspiegel 05.07.2011. http://www.tagesspiegel.de/politik/unstaatenbericht-vereinte-nationen-ruegen-deutsche-sozialpolitik/ 4361232.html. Accessed 22 Feb 2017.

Menke, C., \& Pollmann, A. (2007). Philosophie der Menschenrechte zur Einführung. Hamburg: Junius.

Oevermann, U. (1981). Fallrekonstruktionen und Strukturgeneralisierung als Beitrag der objektiven Hermeneutik zur soziologischstrukturtheoretischen Analyse. http://publikationen.ub.unifrankfurt.de/frontdoor/index/index/docId/4955. Accessed 22 Feb 2017.

Oevermann, U. (2000). Die Methode der Fallrekonstruktion in der Grundlagenforschung sowie der klinischen und pädagogischen Praxis. In K. Kraimer (Ed.), Die Fallrekonstruktion. Sinnverstehen in der sozialwissenschaftlichen Forschung (pp. 58-156). Frankfurt a. Main: Suhrkamp. 
Oevermann, U., Allert, T., Konau, E., \& Krambeck, J. (1979). Die Methodologie einer "objektiven Hermeneutik" und ihre allgemeine forschungslogische Bedeutung in den Sozialwissenschaften. In H.G. Soeffner (Ed.), Interpretative Verfahren in den Sozial- und Textwissenschaften (pp. 352-434). Stuttgart: J. B. Metzler.

OHCHR - Office of the United Nations High Commissioner for Human Rights (2017a). International Covenant on Economic, Social and Cultural Rights. http://www.ohchr.org/EN/ProfessionalInterest/ Pages/CESCR.aspx. Accessed 28 Feb 2017.

OHCHR - Office of the United Nations High Commissioner for Human Rights (2017b). General Comments. http://tbinternet.ohchr.org/ layouts/treatybodyexternal/TBSearch.aspx?Lang=en\&TreatyID= 9\&DocTypeID=11. Accessed 28 Feb 2017.

Pierson, P. (2001). Coping with permanent austerity. Welfare state restructuring in affluent democracies. In P. Pierson (Ed.), The new politics of the welfare state (pp. 410-456). Oxford: University Press.

Reichert, E. (2003). Social work and human rights. A Foundation for Policy and Practice. New York: Columbia University Press.

Reichert, E. (2007). Human rights in the twenty-first century: creating a new paradigm for social work. In E. Reichert (Ed.), Challenges in human rights. A social work perspective (pp. 1-15). New York: Columbia University Press.

Reichertz, J. (2004). Objective hermeneutics and hermeneutic sociology of knowledge. In U. Flick et al. (Eds.), Companion to qualitative research (pp. 290-295). London: Sage.

Riedel, E. (2007). The human right to social security: some challenges. In E. Riedel (Ed.), Social security as a human right. Drafting a general comment on article 9 ICESCR - Some Challenges (pp. 17-28). Heidelberg: Springer.

Saari, J. (2001). Reforming social policy. A study on institutional change in Finland during the 1990s. Turku: Social Policy Association.

Scheinin, M. (2001). The right to social security. In A. Eide, C. Krause, \& A. Rosas (Eds.), Economic, social and cultural rights. A textbook (Second Revised ed., pp. 211-221). Dordrecht a.o: Nijhoff.
Schmid, J. (2007). Arbeitsmarkt- und Beschäftigungspolitik - große Reform mit kleiner Wirkung? In C. Egle \& R. Zohlnhöfer (Eds.), Ende des rot-grünen Projektes (pp. 271-294). Wiesbaden: VS Verlag.

Shue, H. (1996). Basic rights. Subsistence, affluence and U.S. foreign policy (Second ed.). Princeton: Princeton University Press.

Spiegel-Online (2011). Uno kritisiert deutsches Sozialsystem. 06.07.2011. http://www.spiegel.de/politik/deutschland/ staatenbericht-uno-kritisiert-deutsches-sozialsystem-a-772620. html. Accessed 22 Feb 2017.

Stamm, I. (2015). Das Menschenrecht auf soziale Sicherheit. Sozialpolitisches Handeln am Beispiel Deutschlands und Finnlands. Konstanz: UVK Verlag.

Staub-Bernasconi, S. (2007). Economic and social rights: the neglected human rights. In E. Reichert (Ed.), Challenges in human rights. A social work perspective (pp. 138-161). New York: Columbia University Press.

Staub-Bernasconi, S. (2016). Social work and human rights - linking two traditions of human rights in social work. Journal of Human Rights and Social Work, 1, 40-49.

Van Aerschot, P. (2011). Activation policies and the protection of individual rights. A critical assessment of the situation in Denmark, Finland and Sweden. Burlington: Ashgate.

Weiß, N. (2000). Wirtschaftliche, soziale und kulturelle Menschenrechte - vergessene Menschenrechte? In K. P. Fritzsche \& G. Lohmann (Eds.), Menschenrechte zwischen Anspruch und Wirklichkeit (pp. 39-52). Würzburg: Ergon Verlag.

Wernet, A. (2009). Einführung in die Interpretationstechnik der Objektiven Hermeneutik (Third ed.). Wiesbaden: VS Verlag.

Wronka, J. (1998). Human rights and social policy in the $21^{\text {st }}$ century (Revised ed.). Lanham: University Press of America. 